\title{
Ultratrace Determination of $\mathrm{Cr}(\mathrm{VI})$ and $\mathrm{Pb}(\mathrm{II})$ by Microsample Injection System Flame Atomic Spectroscopy in Drinking Water and Treated and Untreated Industrial Effluents
}

\author{
Jameel Ahmed Baig, ${ }^{1,2,3}$ Tasneem Gul Kazi, ${ }^{1}$ Latif Elci, ${ }^{2}$ Hassan Imran Afridi, ${ }^{1}$ \\ Muhammad Irfan Khan, ${ }^{3}$ and Hafiz Muhammad Naseer ${ }^{3}$ \\ ${ }^{1}$ National Centre of Excellence in Analytical Chemistry, University of Sindh, 76080 Jamshoro, Pakistan \\ ${ }^{2}$ Chemistry Department, Pamukkale University, 20017 Denizli, Turkey \\ ${ }^{3}$ Environmental Sciences, International Islamic University, 44000 Islamabad, Pakistan
}

Correspondence should be addressed to Jameel Ahmed Baig; jab_mughal@yahoo.com

Received 15 May 2013; Accepted 29 July 2013

Academic Editor: Miguel de la Guardia

\begin{abstract}
Copyright $@ 2013$ Jameel Ahmed Baig et al. This is an open access article distributed under the Creative Commons Attribution License, which permits unrestricted use, distribution, and reproduction in any medium, provided the original work is properly cited.

Simple and robust analytical procedures were developed for hexavalent chromium ( $\mathrm{Cr}(\mathrm{VI}))$ and lead ( $\mathrm{Pb}(\mathrm{II}))$ by dispersive liquidliquid microextraction (DLLME) using microsample injection system coupled with flame atomic absorption spectrophotometry (MIS-FAAS). For the current study, ammonium pyrrolidine dithiocarbamate (APDC), carbon tetrachloride, and ethanol were used as chelating agent, extraction solvent, and disperser solvent, respectively. The effective variables of developed method have been optimized and studied in detail. The limit of detection of $\mathrm{Cr}(\mathrm{VI})$ and $\mathrm{Pb}(\mathrm{II})$ were 0.037 and $0.054 \mu \mathrm{g} / \mathrm{L}$, respectively. The enrichment factors in both cases were 400 with $40 \mathrm{~mL}$ of initial volumes. The relative standard deviations (RSDs, $n=6)$ were $<4 \%$. The applicability and the accuracy of DLLME were estimated by the analysis of $\mathrm{Cr}(\mathrm{VI})$ and $\mathrm{Pb}$ (II) in industrial effluent wastewater by standard addition method (recoveries $>96 \%$ ). The proposed method was successfully applied to the determination of $\mathrm{Cr}(\mathrm{VI})$ and $\mathrm{Pb}(\mathrm{II})$ at ultratrace levels in natural drinking water and industrial effluents wastewater of Denizli. Moreover, the proposed method was compared with the literature reported method.
\end{abstract}

\section{Introduction}

Lead pollution is one of the most serious environmental problems because of their stability at contaminated sites, the reduction of enzymatic activities, and several other complications in human, plants, and animals [1]. It is introduced into water bodies (lakes, streams, and rivers) through the combustion of fossil fuels, smelting of sulfide ore, and acid mine drainage [2]. Characteristic indications of lead toxicity are abdominal pain, anaemia, headaches and convulsions, chronic nephritis of the kidney, brain damage, and central nervous system disorders [3]. The U.S. Environmental Protection Agency (EPA) has classified lead as a Group B2 human carcinogen [3]. Chromium occurs in higher concentration in the wastes from electroplating, paints, dyes, chrome tanning, and paper industries [4]. $\mathrm{Cr}$ (III) is an essential component having an important role in the glucose, lipid, and protein metabolism, whereas $\mathrm{Cr}(\mathrm{VI})$ is believed to be toxic and carcinogenic [5]. In addition, there is an increasing interest in the determination of $\mathrm{Cr}(\mathrm{VI})$ and $\mathrm{Pb}$ at trace level, because of persistence in the environment and bio-accumulative effect in living organisms [6].

Flame atomic absorption spectrometry (FAAS) is one of the most conventional techniques for the determination of trace metal ions because of the relatively simple and inexpensive equipment [7-9]. However, a preconcentration 
and/or separation step prior the final measurement is usually required for significant precise, sensitive, and accurate determination, in order to bring the analyte concentration into the dynamic range of the detector or to isolate the analyte from the desirable matrix constituents $[3,4,10,11]$.

The preconcentration methods like solvent extraction, ion exchange, adsorption, and coprecipitation were frequently used for trace level analysis of $\mathrm{Cr}(\mathrm{VI})$ and $\mathrm{Pb}(\mathrm{II})$ [12-17]. Liquid-liquid extraction, based on transfer of analyte from the aqueous sample to a water-immiscible solvent, is being widely employed for sample preparation [18]. But these methods are time consuming, needed significant chemical additives, large secondary wastes along procedure, and required complex equipment. Miniaturization of liquid extraction methods can be achieved by a drastic reduction of the extractant phase volume; three new methodologies have been developed, that is, single-drop microextraction, hollow fibre liquid-phase microextraction, and dispersive liquidliquid microextraction [19]. Among them, dispersive liquidliquid microextraction (DLLME) is effectively useful for the separation and pre-concentration of organic and inorganic contaminants in environmental samples in a single step [18, $20,21]$.

For the current study, a new approach has been designed for the simultaneous and selective determination of $\mathrm{Cr}(\mathrm{VI})$ and $\mathrm{Pb}(\mathrm{II})$ at trace level in environmental samples based on DLLME. Ammonium pyrrolidine dithiocarbamate (APDC) has been used as a selective chelating agent for $\mathrm{Cr}(\mathrm{VI})$ and $\mathrm{Pb}(\mathrm{II})[22,23]$. The applicability of DLLME coupled with microsample injection system flame atomic absorption spectroscopy for $\mathrm{Cr}(\mathrm{VI})$ and $\mathrm{Pb}(\mathrm{II})$ preconcentration and separation was adopted as evaluated in our previous work [24]. The influence of the different analytical parameters for both methods was investigated in detailed. The proposed method was applied to tap water, groundwater, and industrial effluent before and after treatment for evaluation of $\mathrm{Cr}(\mathrm{VI})$ and $\mathrm{Pb}(\mathrm{II})$.

\section{Experimental}

2.1. Sampling. Six samples of each type of drinking water (tapwater and groundwater samples) were collected in November 2011 from different sampling sites of Denizli, Turkey (situated between the coordinates $37^{\circ} 46^{\prime} 48^{\prime \prime} \mathrm{N}$ and $29^{\circ} 04^{\prime} 48^{\prime \prime} \mathrm{E}$ in Aegean region). Whereas, the industrial effluent before and after treatment (six samples of each) from well organized industrial zone of Denizli with the assistance of Denizli Environment Quality Laboratory (DENCEV). The proposed methods (details are given below) were performed on the same week of sampling. So, the sample storage was not required.

2.2. Reagents. All solutions were prepared using ultrapure water (resistivity $18.2 \mathrm{M} \Omega / \mathrm{cm}$ ) obtained with a reverse osmosis system (Human Corporation, Seoul, Republic of Korea). Standard solutions of $\mathrm{Cr}(\mathrm{VI})$ and $\mathrm{Pb}(\mathrm{II})$ were prepared by dilution of $1000 \mathrm{ppm}$ certified standard solutions, Fluka (Buchs, Switzerland). Working standard solutions were freshly prepared by appropriate dilution of the stock standard solution. Ammonium pyrrolidine dithiocarbamate (APDC, Fluka) was used as the chelating agent to form the hydrophobic metal complexes. A $5 \%(\mathrm{w} / \mathrm{v})$ of APDC solution was prepared by dissolving suitable amount of APDC in ultrapure water. Buffer of $\mathrm{pH}$ 1-2 was prepared by adding an appropriate amount of hydrochloric acid, Merck (Darmstadt, Germany) and potassium chloride and buffer of $\mathrm{pH}$ 3-6 was prepared by adding an appropriate amount of acetic acid (Merck) and sodium acetate.

2.3. Apparatus. An atomic absorption spectrometer (PerkinElmer, AAnalyst 200), equipped with a chromium hollow cathode lamp, an air-acetylene flame atomizer, and handmade microinjection system, was used for determinations. The wavelength, lamp current, and spectral bandwidth used were $357.9 \mathrm{~nm}, 25 \mathrm{~mA}$, and $0.7 \mathrm{~nm}$, respectively. The $\mathrm{pH}$ measurements were carried out with a pH meter (WTW-pHmeter-720). A centrifuge (Hettich Centrifuge, Germany) was used to accelerate the phase separation process. Microinjector (Hamilton, Switzerland) was used for sediment phase separation.

2.4. Preparation of Handmade Microsample Injection System (MIS). In routine practice, a sample volume of $2-4 \mathrm{~mL}$ is required for a single element determination by FAAS. However, a small volume was obtained by each preconcentration method $(<0.5 \mathrm{~mL})$, whereas there is need for high dilution. To resolve this problem, our group have made a microsample injection system (MIS), coupled to the nebulizer needle using a PTFE capillary tube (length of $12 \mathrm{~cm}$ ) attached with yellow micropipette tip (capacity $20-200 \mu \mathrm{L}$ ) as reported in our previous work [24]. For simultaneous determination of $\mathrm{Cr}(\mathrm{VI})$ and $\mathrm{Pb}(\mathrm{II}), 100 \mathrm{~mL}$ was used for each analysis.

2.5. Dispersive Liquid-Liquid Microextraction. The $\mathrm{Cr}(\mathrm{VI})$ and $\mathrm{Pb}$ (II) were determined by DLLME, using a complexing reagent (APDC) and resulted complex was enriched into extraction solvent through disperser solvent. To optimize DLLME, four replicate of sub-samples $(40 \mathrm{~mL})$ of standard solution containing $10 \mu \mathrm{g} \mathrm{L}^{-1} \mathrm{Cr}(\mathrm{VI})$ and $\mathrm{Pb}(\mathrm{II})$ in PTFE tubes $(50 \mathrm{~mL}$ in capacity). The $\mathrm{pH}$ was adjusted with appropriate buffer solution in the range of 1-6. Then, added 0.05$2 \%(\mathrm{w} / \mathrm{v})$ APDC and 1-4 mL ethanol containing 100-400 $\mu \mathrm{L}$ tetrachloride carbon was rapidly injected into the aqueous solution with a $2.5 / 5.0 \mathrm{~mL}$ syringe. As a result, a turbid phase immediately was formed. The acquired solution was centrifuged at $3000 \mathrm{rpm}$ for $5 \mathrm{~min}$. The $\mathrm{CCl}_{4}$ as sediment phase was separated in the range of $80-90 \mu \mathrm{L}$ by microinjector into $2 \mathrm{~mL}$ glass vial. The residual phase was vaporized to dryness by electrical hot plate and dissolved in $0.1 \mathrm{~mL}$ of $0.1 \mathrm{~mol} / \mathrm{L}$ $\mathrm{HNO}_{3}$. The final solution was determined by MIS-FAAS.

2.6. Determination of $\mathrm{Cr}(\mathrm{VI})$ and $\mathrm{Pb}(\mathrm{II})$ in Water and Industrial Effluents. $40 \mathrm{~mL}$ of replicate four subsamples of tap water, groundwater, and industrial effluent were filtered with ordinary filter papers to removed unsalable matrices and taken in PTFE tubes (50 $\mathrm{mL}$ in capacity). Then, treated with 


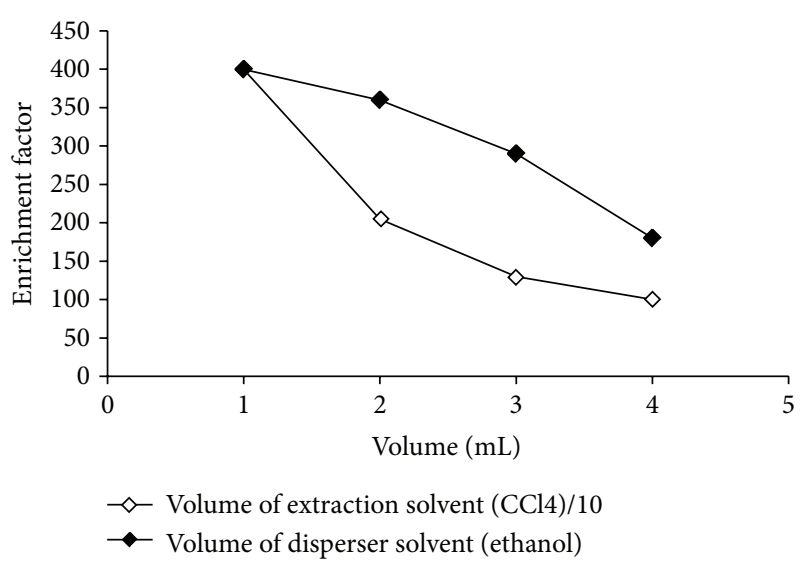

FIGURE 1: Influence of volume of the extraction solvent $\left(\mathrm{CCl}_{4}\right)$ and dispersive solvent (ethanol) on the enrichment factor of $\mathrm{Cr}(\mathrm{VI})$ and $\mathrm{Pb}$ (II) at $40 \mathrm{~mL}$ initial volume of water samples $0.25 \%$ APDC, $\mathrm{pH}$ 3.00, and $0.01 \mathrm{mg} / \mathrm{L} \mathrm{Cr}(\mathrm{VI}) / \mathrm{Pb}(\mathrm{II})$.

developed DLLME as illustrated above for determination of $\mathrm{Cr}(\mathrm{VI})$ and $\mathrm{Pb}(\mathrm{II})$, respectively.

\section{Results and Discussion}

In order to attain higher enrichment factor and significant recovery percentages of $\mathrm{Cr}(\mathrm{VI})$ and $\mathrm{Pb}(\mathrm{II})$ by DLLME coupled with MIS-FAAS, the characteristic parameters were investigated in detail. Each experiment was repeated four times and the results were presented with mean \pm standard deviation at $95 \%$ confidence intervals.

3.1. Influence of the Extraction Solvent Type and Volume. The extraction solvents with higher density than water were mostly used for DLLME procedure. Among different solvents, $\mathrm{CHCl}_{3}$ and $\mathrm{CCl}_{4}$ were selected for pre-concentration of the $\mathrm{Cr}(\mathrm{VI})$ and $\mathrm{Pb}(\mathrm{II})$ on the basis of their high density and vapour pressure as well as less water solubility (19). Sample solutions were tested using $1.0 \mathrm{~mL}$ of ethanol (disperser solvent), which contains $100 \mu \mathrm{L}$ of understudied extraction solvents and rapidly injected into $40.0 \mathrm{~mL}$ of the aqueous sample resulted from complex formation reaction. In this experiment, $\mathrm{CCl}_{4}$ and $\mathrm{CHCl}_{3}$ resulted in enrichment factors of $400 \pm 5.0$ and $380 \pm 8.0$, respectively. $\mathrm{CCl}_{4}$ established the maximum enrichment factor as compared to $\mathrm{CHCl}_{3}$ because of its low solubility, less viscosity, and polarity (19). The formed sediment phase can easily be separated by a microinjector. As a result, $\mathrm{CCl}_{4}$ was chosen as best extraction solvent.

To evaluate the effect of the extraction solvent volume, solutions containing different volumes of $\mathrm{CCl}_{4}(100$ to $400 \mu \mathrm{L}$ ) were studied (Figure 1). It was observed that the enrichment factor of simultaneous preconcentration of $\mathrm{Cr}(\mathrm{VI})$ and $\mathrm{Pb}(\mathrm{II})$ by DLLME was decreased with increasing the volume of $\mathrm{CCl}_{4}$ (Figure 1). This is due to the large volume of sediment phase ( 80 to $320 \mu \mathrm{L}$ ). At the end of experimental studies $100 \mu \mathrm{L}$ volume of $\mathrm{CCl}_{4}$ was selected for the subsequent investigations.
3.2. Influence of the Disperser Solvent Type and Volume. In DLLME, the dispersive solvent must be miscible both aqueous phase and extraction solvent. Thus, different solvents $\left(\mathrm{CH}_{3} \mathrm{CHO}, \mathrm{CH}_{3} \mathrm{CN}, \mathrm{CH}_{3} \mathrm{CH}_{2} \mathrm{OH}\right.$, and $\left.\mathrm{CH}_{3} \mathrm{OH}\right)$ were tested as disperser solvent using $1.00 \mathrm{~mL}$ of each disperser solvent containing $100 \mu \mathrm{L} \mathrm{CCl}_{4}$ (extraction solvent). However, the enrichment factors obtained by each studied dispersive solvent have no significant difference $(P>0.05)$. But, for the lowest toxicity and standard deviation of $\mathrm{CH}_{3} \mathrm{CH}_{2} \mathrm{OH}$, further studies it have been chosen. The effect of the volume of $\mathrm{CH}_{3} \mathrm{CH}_{2} \mathrm{OH}$ on the extraction recovery was also carried out. The effect of different volumes of $\mathrm{CH}_{3} \mathrm{CH}_{2} \mathrm{OH}$ (1.00$4.00 \mathrm{~mL}$ ) was carried out at optimum experimental conditions as shown in Figure 1. The enrichment factor decreased, when the $\mathrm{CH}_{3} \mathrm{CH}_{2} \mathrm{OH}$ volume increased. Thus, $1.00 \mathrm{~mL}$ of $\mathrm{CH}_{3} \mathrm{CH}_{2} \mathrm{OH}$ was chosen for further study.

3.3. Effect of the Extraction Time. Extraction time can be defined as the time interval between injecting the mixture of disperser solvent $\left(\mathrm{CH}_{3} \mathrm{CH}_{2} \mathrm{OH}\right)$ and extraction solvent $\left(\mathrm{CCl}_{4}\right)$ into sample before starting to centrifuge [19]. Dependence of the enrichment factor upon extraction time was studied within a range of $5.0 \mathrm{sec}-5.0 \mathrm{~min}$, while the experimental conditions were kept constant. It is observed that extraction time has no significant effect on the enrichment factor and extraction efficiency of DLLME and phase separation is completed in 5.0 to $10.0 \mathrm{sec}$.

3.4. Salt Effect. The solubility of understudied analytes and organic extraction solvent in aqueous phase are usually decreased with the increase of salt concentration, which is favorable for reaching high recovery. Therefore, influence of salt concentration was evaluated at $0.05-4.00 \%(\mathrm{w} / \mathrm{v})$ $\mathrm{NaCl}$ levels while other parameters were kept constant. The results showed that salt addition up to $1.00 \%$ did not affect the enrichment factor considerably. By increasing the ionic strength (from $1.00 \%$ to $4.00 \%$ ), the solubility of the extraction solvent in the aqueous phase diminishes. As a result, the volume of the sediment phase increases from almost 110 to $130 \mu \mathrm{L}$, which decreases the enrichment factor. The developed method can be applicable for separation of chromium from saline solutions up to $1.00 \%$.

3.5. Influence of Sample $p H$ and Concentration of APDC. The $\mathrm{pH}$ plays an important role in the extraction of inorganic compounds especially chromium in environmental samples for the complex formation reaction with complexing reagent including APDC. In this experiment, the effect of $\mathrm{pH}$ on the extraction performance within the range of 1-6 was investigated for $\mathrm{Cr}(\mathrm{VI})$ and $\mathrm{Pb}(\mathrm{II})$ as shown in Figure 2. It can be observed that the recovery of $\mathrm{Cr}(\mathrm{VI})$ was found to be high with the increase of $\mathrm{pH}$ value (2 to 4 ) and to abruptly fall down when $\mathrm{pH}$ was increased to 4 (Figure 2). At more acidic conditions, $\mathrm{HCr}_{2} \mathrm{O}_{7}{ }^{-}$and $\mathrm{Cr}_{2} \mathrm{O}_{7}{ }^{2-}$ dimers become the dominant $\mathrm{Cr}(\mathrm{VI})$ form and the $\mathrm{pK}_{\mathrm{a} 1}$ and $\mathrm{pK}_{\mathrm{a} 2}$ values of these ions are 0.74 and 6.49 , respectively $[24,25]$. In aqueous solutions having a lower $\mathrm{pH}$, the dichromate will be present primarily in its protonated form, that is, $\mathrm{HCr}_{2} \mathrm{O}_{7}^{-}$, and it 


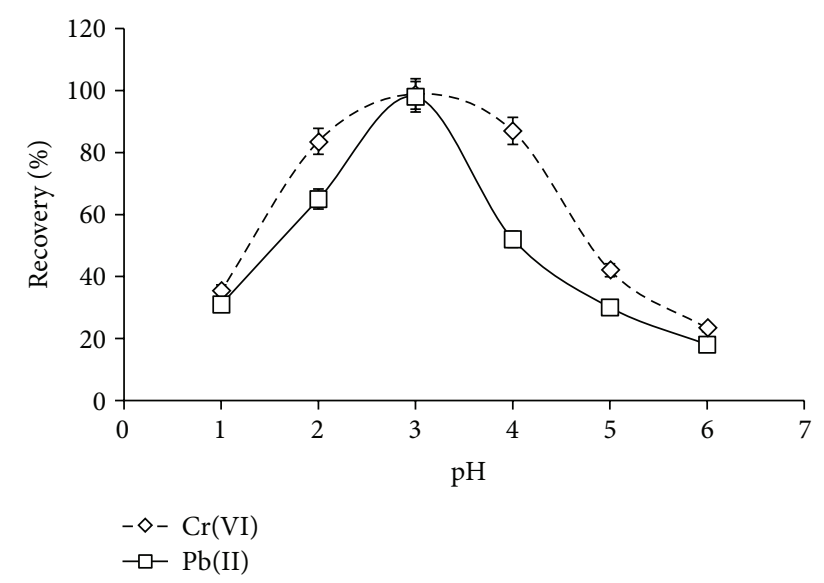

FIgURE 2: Influence of sample $\mathrm{pH}$ on DLLME at $40 \mathrm{~mL}$ initial volume of water samples $0.25 \% \mathrm{APDC}, 100 \mu \mathrm{L} \mathrm{CCl}, 1.00 \mathrm{~mL}$ of ethanol, and $0.01 \mathrm{mg} / \mathrm{L} \mathrm{Cr}(\mathrm{VI}) / \mathrm{Pb}(\mathrm{II})$.

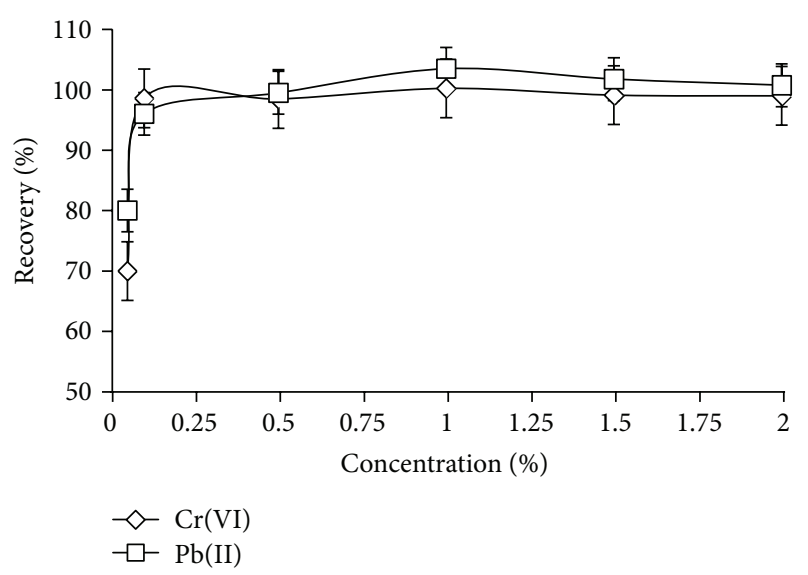

FIGURE 3: Influence of APDC concentration on DLLME for Cr(VI) and $\mathrm{Pb}(\mathrm{II})$ at $40 \mathrm{~mL}$ initial volume of water samples $\mathrm{pH} 2.0$ and $0.10 \mathrm{mg} / \mathrm{L} \mathrm{Cr}(\mathrm{VI}) / \mathrm{Pb}(\mathrm{II})$.

was observed in most of studies that the APDC mostly forms complexes with $\mathrm{HCr}_{2} \mathrm{O}_{7}{ }^{-}$ions $[24,25]$. In case of $\mathrm{Pb}(\mathrm{II})$, the obtained results show that the recoveries percentage of $\mathrm{Pb}(\mathrm{II})$ is high in the $\mathrm{pH} 3.0$ (Figure 2). Therefore, the $\mathrm{pH} 3.0$ was selected for simultaneous optimum recoveries of $\mathrm{Cr}(\mathrm{VI})$ and $\mathrm{Pb}(\mathrm{II})$.

The effect of the APDC amount in the range of 0.05$2 \%(\mathrm{v} / \mathrm{v})$ for the simultaneous preconcentration of $\mathrm{Cr}(\mathrm{VI})$ and $\mathrm{Pb}$ (II) was studied. In this case, the enrichment factor increased up to $0.1 \%(\mathrm{v} / \mathrm{v})$ APDC, reaching a plateau, which is considered as maximum extraction (Figure 3 ). For simultaneously determination of $\mathrm{Cr}(\mathrm{VI})$ and $\mathrm{Pb}(\mathrm{II})$ was recorded in the range of $0.10-2.00 \%(\mathrm{~m} / \mathrm{v})$. On the behalf of resulted data, $0.25 \%(\mathrm{~m} / \mathrm{v})$ APDC solution in water was adopted for further study. The $0.25 \%(\mathrm{v} / \mathrm{v})$ APDC was chosen as the optimal amount for the $\mathrm{Cr}(\mathrm{VI})$ and $\mathrm{Pb}(\mathrm{II})$ to prevent any interference.

3.6. Effect of the Coexisting Ions. In order to assess the feasibility of DLLME for analytical applications, the effect of
TABLE 1: Tolerable levels of concomitant ions for the extraction of $10 \mu \mathrm{g} / \mathrm{L} \mathrm{Cr}(\mathrm{VI})$ and $\mathrm{Pb}(\mathrm{II})(N=4)$.

\begin{tabular}{|c|c|c|}
\hline \multirow{2}{*}{ Ions } & \multicolumn{2}{|c|}{ Tolerable levels $(\mathrm{mg} / \mathrm{L})$} \\
\hline & $\mathrm{Cr}(\mathrm{VI})$ & $\mathrm{Pb}(\mathrm{II})$ \\
\hline $\mathrm{Na}^{+}, \mathrm{Cl}^{-}$ & \multicolumn{2}{|c|}{1,000} \\
\hline $\mathrm{Li}^{+}, \mathrm{K}^{+}, \mathrm{Ca}^{2+}, \mathrm{Mg}^{2+}$ & \multicolumn{2}{|c|}{250} \\
\hline $\mathrm{SO}_{4}^{-2}, \mathrm{NO}_{3}^{-}$ & \multicolumn{2}{|c|}{100} \\
\hline $\begin{array}{l}\mathrm{Cu}(\mathrm{II}), \mathrm{Fe}(\mathrm{II}), \mathrm{Se}(\mathrm{II}), \mathrm{As}(\mathrm{III}), \mathrm{Co}(\mathrm{II}), \\
\mathrm{Hg}(\mathrm{II}), \mathrm{Mn}(\mathrm{II}), \mathrm{Cr}(\mathrm{III}), \mathrm{Ni}(\mathrm{II}), \mathrm{Al}(\mathrm{III}), \\
\mathrm{Zn}(\mathrm{II})\end{array}$ & \multicolumn{2}{|c|}{50} \\
\hline
\end{tabular}

TABLE 2: The results for tests of addition/recovery for Cr(VI) by DLLME in industrial wastewater samples $(n=6)$.

\begin{tabular}{ccccc}
\hline & $\begin{array}{c}\text { Amount added } \\
(\mu \mathrm{g} / \mathrm{L})\end{array}$ & $\begin{array}{c}\text { Found values } \\
\text { Mean } \pm \mathrm{SD} \\
(\mu \mathrm{g} / \mathrm{L})\end{array}$ & \%Recovery & \\
\hline & - & $12.5 \pm 2.4$ & - & - \\
$\mathrm{Cr}(\mathrm{VI})$ & 10 & $24.7 \pm 0.3$ & $110.0 \pm 1.5$ & 1.4 \\
& 25 & $40.7 \pm 0.7$ & $108.0 \pm 1.8$ & 1.7 \\
& 50 & $61.4 \pm 3.4$ & $98.5 \pm 3.3$ & 3.4 \\
\hline & - & $10.4 \pm 1.5$ & - & - \\
$\mathrm{Pb}(\mathrm{II})$ & 10 & $20.5 \pm 0.4$ & $100.5 \pm 2.2$ & 2.0 \\
& 25 & $35.2 \pm 0.8$ & $99.4 \pm 1.7$ & 2.3 \\
& 50 & $59.8 \pm 1.8$ & $99.0 \pm 1.2$ & 3.0 \\
\hline${ }^{\mathrm{a}} \%$ Recovery & $\left(C_{\text {after spiked }} /\left(C_{\text {intial }}+C_{\text {spiked }}\right)\right) \times 100$. &
\end{tabular}

some foreign ions which interfere with $\mathrm{Cr}(\mathrm{VI})$ and $\mathrm{Pb}(\mathrm{II})$ ion and/or often accompany analyte ions in various real environmental samples was investigated with the optimized conditions (Table 1). It is a general rule for analytical chemistry that any matrix was considered to interfere if the resulted FAAS signal of understudied analyte was varied $\pm 5.0 \%$. The recoveries of $\mathrm{Cr}(\mathrm{VI})$ and $\mathrm{Pb}(\mathrm{II})$ were almost quantitative in the presence of an excessive amount of the possible interfering cations and anions (Table 1).

3.7. Analytical Figure of Merits. The analytical characteristics of the proposed procedure were calculated under the optimized conditions. These characteristics were calculated using the values of the signals for analytical curve. The calibration and standard addition graphs were obtained for $\mathrm{Cr}(\mathrm{VI})$ and $\mathrm{Pb}(\mathrm{II})$, determined by microsample injection system flame atomic absorption spectrometry (MIS-FAAS). The linear range of the calibration graphs obtained in the concentration range from 1 to $10 \mu \mathrm{g} / \mathrm{L}$ for $\mathrm{Cr}(\mathrm{VI})$ and $\mathrm{Pb}(\mathrm{II})$. The limit of detection (LOD) and limit of quantification (LOQ) were calculated as $3 \times S_{b} / m$ and $10 \times S_{b} / m$, respectively, where $S_{b}$ is the standard deviation of the blank $(n=10)$ and $m$ is slope of the linear section of calibration graph. The LODs of $\mathrm{Cr}(\mathrm{VI})$ and $\mathrm{Pb}(\mathrm{II})$ were found to be 0.037 and $0.054 \mu \mathrm{g} / \mathrm{L}$, whereas, LOQs were 0.124 and $0.182 \mu \mathrm{g} \mathrm{L^{-1 }}$, respectively. The calibration curve of $\mathrm{Cr}(\mathrm{VI})$ and $\mathrm{Pb}(\mathrm{II})$ for over this interval was determined to be $A=2.10 \times 10^{-2} \times$ $[\mathrm{Cr}(\mathrm{VI})]+6.00 \times 10^{-5}$ and $A=2.40 \times 10^{-2} \times[\mathrm{Pb}(\mathrm{II})]+$ 
TABLE 3: Comparative data of analytical characteristics of the literature reported methods and proposed method.

\begin{tabular}{|c|c|c|c|c|c|c|c|}
\hline Analyte(s) & $\begin{array}{l}\text { Analytical } \\
\text { technique }\end{array}$ & Extraction phase & $\begin{array}{c}\text { Extraction } \\
\text { time } \\
(\mathrm{min})\end{array}$ & $\begin{array}{c}\text { Enrichment } \\
\text { factor }\end{array}$ & $\begin{array}{l}\mathrm{LOD} \\
(\mu \mathrm{g} / \mathrm{L})\end{array}$ & RSD (\%) & Ref. \\
\hline $\mathrm{Cr}(\mathrm{VI})$ & FAAS & $\begin{array}{l}\text { Ethyl xanthate } \\
\text { complex onto } \\
\text { naphthalene }\end{array}$ & 15 & 100 & 0.500 & 3.1 & [25] \\
\hline $\mathrm{Cr}(\mathrm{VI})$ & CE-FAAS & $\mathrm{Dy}_{2} \mathrm{O}_{3}$ aqueous solution & 20 & 100 & 0.780 & - & {$[26]$} \\
\hline $\mathrm{Cr}(\mathrm{VI})$ & $\begin{array}{l}\text { UPAILDLLME- } \\
\text { ETAAS }\end{array}$ & $\mathrm{APDC} /[\mathrm{Hmim}]\left[\mathrm{PF}_{6}\right]$ & $5-6$ & 300 & 0.07 & 9.2 & {$[22]$} \\
\hline $\mathrm{Cr}(\mathrm{VI})$ & $\begin{array}{l}\text { DLLME-UV-Vis } \\
\text { spectrophotometry }\end{array}$ & DIC/Toluene & - & - & 30.0 & $<5.0$ & {$[27]$} \\
\hline $\mathrm{Cr}(\mathrm{VI})$ & DLLME-ETAAS & $\mathrm{APDC} / \mathrm{CCl}_{4}$ & - & 171 & 0.00596 & 3.02 & {$[28]$} \\
\hline $\begin{array}{l}\mathrm{Cr}(\mathrm{VI}) \\
\mathrm{Cr}(\mathrm{T})\end{array}$ & DLLME-FAAS & $\begin{array}{c}\mathrm{APDC}+\mathrm{EDTA} / \\
\mathrm{CCl}_{4}\end{array}$ & 0.08 & $\begin{array}{l}275 \\
262\end{array}$ & $\begin{array}{l}0.07 \\
0.08\end{array}$ & $\begin{array}{l}2.0 \\
2.6\end{array}$ & {$[29]$} \\
\hline $\mathrm{Cr}(\mathrm{VI})$ & DLLME-ETAAS & $\begin{array}{c}\mathrm{APDC}+ \\
\left(\left[\mathrm{C}_{8} \mathrm{MIm}\right]\left[\mathrm{NTf}_{2}\right]\right)\end{array}$ & - & 300 & 0.002 & & {$[30]$} \\
\hline $\mathrm{Cr}(\mathrm{VI})$ & $\begin{array}{l}\text { DLLME-MIS- } \\
\text { FAAS }\end{array}$ & $\mathrm{APDC} / \mathrm{CCl}_{4}$ & $0.08-0.16$ & 400 & 0.037 & $<4.0$ & $\begin{array}{c}\text { Current } \\
\text { study }\end{array}$ \\
\hline $\mathrm{Pb}(\mathrm{II})$ & CP-FAAS & $\begin{array}{c}\text { 5-Chloro-2- } \\
\text { hydroxyaniline-Cu(II) }\end{array}$ & 10 & 50 & 2.72 & $<5.0$ & {$[31]$} \\
\hline $\mathrm{Pb}(\mathrm{II})$ & MF-FAAS & Cellulose nitrate/ $\mathrm{HNO}_{3}$ & - & 60 & 0.30 & $<10$ & {$[32]$} \\
\hline $\mathrm{Pb}(\mathrm{II})$ & SDME-ETAAS & $\mathrm{DDTP} / \mathrm{CHCl}_{3}$ & 7 & 52 & 0.20 & $<4.0$ & {$[33]$} \\
\hline $\mathrm{Pb}(\mathrm{II})$ & IL-SDME-ETAAS & $\begin{array}{c}\text { 5-Br-PADAP/CYPHOS } \\
\text { IL } 101\end{array}$ & 15 & 32 & 0.0032 & 4.9 & {$[34]$} \\
\hline $\mathrm{Pb}(\mathrm{II})$ & IL-SDME-ETAAS & $\mathrm{APDC} /\left[\mathrm{C}_{4} \mathrm{MIM}\right]\left[\mathrm{PF}_{6}\right]$ & 7 & 76 & 0.015 & 5.2 & {$[35]$} \\
\hline $\mathrm{Pb}(\mathrm{II})$ & DLLME-FAAS & $\mathrm{DDTP} / \mathrm{CCl}_{4}$ & 0.08 & 450 & 0.50 & 3.8 & {$[36]$} \\
\hline $\mathrm{Pb}(\mathrm{II})$ & DLLME-GFAAS & $\mathrm{DDTP} / \mathrm{CCl}_{4}$ & $<3$ & 150 & 0.02 & 2.5 & {$[37]$} \\
\hline $\mathrm{Pb}(\mathrm{II})$ & DLLME-GFAAS & $\mathrm{PMBP} / \mathrm{CCl}_{4}$ & 5 & 78 & 0.0039 & 3.2 & {$[38]$} \\
\hline $\mathrm{Pb}(\mathrm{II})$ & $\begin{array}{l}\text { DLLME-MIS- } \\
\text { FAAS }\end{array}$ & $\mathrm{APDC} / \mathrm{CCl}_{4}$ & $0.08-0.16$ & 400 & 0.054 & $<5.0$ & $\begin{array}{c}\text { Current } \\
\text { study }\end{array}$ \\
\hline
\end{tabular}

Ammonium pyrrolidine dithiocarbamate (APDC), 2-(5-bromo-2-pyridylazo)-5-diethylaminophenol (5-Br-PADAP), 1-butyl-3-methylimidazolium hexafluorophosphate $\left[\mathrm{C}_{4} \mathrm{MIM}\right]\left[\mathrm{PF}_{6}\right]$, charge coupled device $(\mathrm{CCD})$, coprecipitation flame atomic absorption spectroscopy (CE-FAAS), O,O-diethyldithiophosphate (DDTP), methylindocarbocyanine (DIC), 1,5-diphenylcarbazide (DPC), 1-hexyl-3-methylimidazolium hexafluorophosphate ([Hmim] $\left.\left[\mathrm{PF}_{6}\right]\right)$, electrothermal atomic absorption spectroscopy (ETAAS), graphite furnace atomic absorption spectroscopy (GFAAS), inductively coupled plasma-optical emission spectrometry (ICP-OES), pyrrolidine dithiocarbamate (PDC), 1-phenyl-3-methyl-4-benzoyl-5-pyrazolone (PMBP), single drop microextraction (SDME), sequential injection analysis (SIA), tetradecyl(trihexyl)phosphonium chloride (CYPHOS IL 101), ultrasonic probe-assisted ionic liquid dispersive liquid-liquid microextraction (UPAILDLLME), 1-octyl-3-methylimidazolium bis(trifluoromethanesulfonyl)imide ([C $\left.\left.\mathrm{C}_{8} \mathrm{MIm}\right]\left[\mathrm{NTf}_{2}\right]\right)$.

$1.00 \times 10^{-3}$, respectively, where $A$ is the analytical signal, measured as absorbance, and $[\mathrm{Cr}(\mathrm{VI})]$ and $[\mathrm{Pb}(\mathrm{II})]$ are the concentrations of chromium and lead, respectively $(\mu \mathrm{g} / \mathrm{L})$. The correlation coefficients $(r)$ were 0.999 and 0.998 for $\mathrm{Cr}(\mathrm{VI})$ and $\mathrm{Pb}(\mathrm{II})$, respectively. The \%RSD of both methods was evaluated with $40.00 \mathrm{~mL}$ from the solution containing the $0.01 \mu \mathrm{g} / \mathrm{L} \mathrm{Cr}(\mathrm{VI}) / \mathrm{Pb}(\mathrm{II})$ and was achieved $<5 \%(n=4)$. The enrichment factor (EF) was calculated by the ratio of $\mathrm{Cr}(\mathrm{VI}) / \mathrm{Pb}(\mathrm{II})$ concentration in sediment phase and initial concentration in original solution. Finally, the enrichment factor 400 was obtained for simultaneous preconcentration of $\mathrm{Cr}(\mathrm{VI})$ and $\mathrm{Pb}(\mathrm{II})$.

The reliability of the simplest calibration against aqueous standard solutions for DLLME was verified by means of spiking experiments at three concentration levels of $\mathrm{Cr}(\mathrm{VI})$ and $\mathrm{Pb}$ (II) in the range of 10 to $50 \mu \mathrm{g} / \mathrm{L}$ with the maximum recovery percentage (98.5-110\%) as summarized in Table 2.
A good agreement was obtained between the added and measured analyte concentrations $(P<0.001)$.

3.8. Comparison of the Proposed Methods with the Other Literature Reported Method. Comparison of the proposed method with other approaches reported in the literature for preconcentration and determination of $\mathrm{Cr}(\mathrm{VI})$ and $\mathrm{Pb}$ (II) is represented in Table 3 . The results showed that the extraction time for proposed DLLME is short (5-10 sec). The enrichment factors, LODs and \%RSDs of DLLME, are comparable with those reported in the literature $[22,25-$ 37]. The proposed methods (DLLME and CECP) coupled with MIS-FAAS are simple, most sensitive, and selective. Therefore, these methods could successfully be applied to the monitoring of trace amounts of chromium species in environmental, biological, and soil samples. 
TABLE 4: Analytical results of $\mathrm{Cr}(\mathrm{VI})$ and $\mathrm{Pb}(\mathrm{II})(\mu \mathrm{g} / \mathrm{L})$ in drinking water and industrial effluents (Denizli, Turkey).

\begin{tabular}{lcc}
\hline Origin of water (no. of samples) & $\mathrm{Cr}(\mathrm{VI})$ & $\mathrm{Pb}(\mathrm{II})$ \\
\hline Groundwater $(n=6)$ & $3.7 \pm 1.8$ & $32.6 \pm 1.6$ \\
Tap water $(n=6)$ & $2.6 \pm 0.5$ & $10.4 \pm 2.1$ \\
Untreated industrial effluent $(n=4)$ & $23.3 \pm 5.3$ & $91.7 \pm 1.8$ \\
Treated industrial effluent $(n=4)$ & $9.6 \pm 4.5$ & $70.3 \pm 1.2$ \\
\hline
\end{tabular}

3.9. Application to Real Samples. The simultaneous preconcentration of $\mathrm{Cr}(\mathrm{VI})$ and $\mathrm{Pb}(\mathrm{II})$ in tap water, groundwater, and industrial effluents before and after treatment was studied using DLLME (Table 4). $\mathrm{Cr}(\mathrm{VI})$ and $\mathrm{Pb}(\mathrm{II})$ contents in tapwater and groundwater varied in the ranges 0.0 to 3.2 and 0.0 to 6.0 and (8.0 to 13.0 and 31.0 to $34.0 \mu \mathrm{g} / \mathrm{L}$, respectively. The $\mathrm{Cr}(\mathrm{VI})$ and $\mathrm{Pb}(\mathrm{II})$ contents in tap water samples were fallen within the WHO maximum contaminant level 50 and $10 \mu \mathrm{g} / \mathrm{L}$, respectively. The $\mathrm{Cr}(\mathrm{VI})$ and $\mathrm{Pb}(\mathrm{II})$ contents were found higher in groundwater as compared to tap water, because the natural abundance of geochemicals containing $\mathrm{Cr}(\mathrm{VI})$ and $\mathrm{Pb}(\mathrm{II})$. The high contents of $\mathrm{Cr}(\mathrm{VI})$ and $\mathrm{Pb}(\mathrm{II})$ in groundwater may cause hematological damage, brain damage, anemia, kidney malfunctioning, infections of skin and gastrointestinal tract, and carcinoma of the lung [38, 39]. But Cr(VI) in ground water of Denizli did not exceed WHO regulated values $(50.0 \mu \mathrm{g} / \mathrm{L})$ of $\mathrm{Cr}(\mathrm{VI})$ for drinking water. Thus, both understudied waters (tapwater and groundwater) have safe levels of $\mathrm{Cr}(\mathrm{VI})$ for local community as natural drinking water sources. But $\mathrm{Pb}$ (II) in groundwater was found to be high, which is not suitable for drinking as well as cooking.

The $\mathrm{Cr}(\mathrm{VI})$ and $\mathrm{Pb}(\mathrm{II})$ in the tannery effluent samples before and after treatment were also determined by developed preconcentration method as shown in Table 4. The Cr(VI) and $\mathrm{Pb}(\mathrm{II})$ were observed in excess amount in untreated industrial water (Table 4), because of human activities especially through the production of wastewater in electroplating, tanning, textile, and dyestuff industries present in industrial zone. However, the Denizli municipality has a well-organized biological treatment plant based upon system of classical activated sludge for the recycling of industrial and municipality wastewater. The industrial samples after treatment have less amount of $\mathrm{Cr}(\mathrm{VI})$ and $\mathrm{Pb}(\mathrm{II})$; removal percentage of $\mathrm{Cr}(\mathrm{VI})$ and $\mathrm{Pb}(\mathrm{II})$ by biological treatment plant was 30 to $50 \%$ as shown in Table 4.

\section{Conclusion}

The DLLME coupled with MIS-FAAS was developed for simultaneous ultratrace level of $\mathrm{Cr}(\mathrm{VI})$ and $\mathrm{Pb}(\mathrm{II})$ determination in drinking water and industrial effluent before and after treatment. Proposed method proved to be fast, simple, inexpensive, and reproducible for the ultratrace level of $\mathrm{Cr}(\mathrm{VI})$ and $\mathrm{Pb}(\mathrm{II})$ with high enrichment factor (400). In this work, the use of handmade microsample injection systems for ultratrace level determination of $\mathrm{Cr}(\mathrm{VI})$ and $\mathrm{Pb}$ (II) offers several advantages including low cost, reusable and required less volume of sample with high recoveries percentage as compared to continuous flow FAAS.

\section{Acknowledgments}

The authors gratefully acknowledge the Scientific and Technical Research Council of Turkey (TUBITAK) and Analytical Section of Chemistry Department, Pamukkale University Denizli, for financial assistance and laboratory and instrumental facilities for postdoctoral. Studies. Moreover, it would be acknowledged to Nilgün ELYAS laboratory supervisor of Denizli Environment Quality Laboratory (DENCEV) and research assistant of Chemistry Department of Pamukkale University for sampling assistance.

\section{References}

[1] F. Shah, T. G. Kazi, H. I. Afridi et al., "The influence of environmental exposure on lead concentrations in scalp hair of children in Pakistan," Ecotoxicology and Environmental Safety, vol. 74, no. 4, pp. 727-732, 2011.

[2] P. Chooto, P. Wararatananurak, and C. Innuphat, "Determination of trace levels of $\mathrm{Pb}$ (II) in tap water by anodic stripping voltammetry with boron-doped diamond electrode," ScienceAsia, vol. 36, no. 2, pp. 150-156, 2010.

[3] Y. Wang, S. Gao, X. Zang, J. Li, and J. Ma, "Graphene-based solid-phase extraction combined with flame atomic absorption spectrometry for a sensitive determination of trace amounts of lead in environmental water and vegetable samples," Analytica Chimica Acta, vol. 716, pp. 112-118, 2012.

[4] L. Elci, U. Divrikli, A. Akdogan, A. Hol, A. Cetin, and M. Soylak, "Selective extraction of chromium(VI) using a leaching procedure with sodium carbonate from some plant leaves, soil and sediment samples," Journal of Hazardous Materials, vol. 173, no. 1-3, pp. 778-782, 2010.

[5] M. Korolczuk and A. Stępniowska, "Determination of Cr(VI) in the presence of high excess of a $\mathrm{Cr}$ (III) by adsorptive stripping voltammetry," Talanta, vol. 88, pp. 427-431, 2012.

[6] A. N. Anthemidis and S.-J. V. Koussoroplis, "Determination of chromium(VI) and lead in water samples by on-line sorption preconcentration coupled with flame atomic absorption spectrometry using a PCTFE-beads packed column," Talanta, vol. 71, no. 4, pp. 1728-1733, 2007.

[7] T. Minami, Y. Sohrin, and J. Ueda, "Determination of chromium, copper and lead in river water by graphite-furnace atomic absorption spectrometry after coprecipitation with terbium hydroxide," Analytical Sciences, vol. 21, no. 12, pp. 15191521, 2005.

[8] S. Baytak and A. R. Türker, "Determination of lead and nickel in environmental samples by flame atomic absorption spectrometry after column solid-phase extraction on Ambersorb-572 with EDTA," Journal of Hazardous Materials, vol. 129, no. 1-3, pp. 130-136, 2006.

[9] G. Döner and A. Ege, "Determination of copper, cadmium and lead in seawater and mineral water by flame atomic absorption spectrometry after coprecipitation with aluminum hydroxide," Analytica Chimica Acta, vol. 547, no. 1, pp. 14-17, 2005.

[10] K. Kiran, K. S. Kumar, B. Prasad, K. Suvardhan, R. B. Lekkala, and K. Janardhanam, "Speciation determination of chromium(III) and (VI) using preconcentration cloud point extraction 
with flame atomic absorption spectrometry (FAAS)," Journal of Hazardous Materials, vol. 150, no. 3, pp. 582-586, 2008.

[11] P. Liang, Q. Ding, and Y. Liu, "Speciation of chromium by selective separation and preconcentration of $\mathrm{Cr}$ (III) on an immobilized nanometer titanium dioxide microcolumn," Journal of Separation Science, vol. 29, no. 2, pp. 242-247, 2006.

[12] Á. Béni, R. Karosi, and J. Posta, "Speciation of hexavalent chromium in waters by liquid-liquid extraction and GFAAS determination," Microchemical Journal, vol. 85, no. 1, pp. 103108, 2007.

[13] H. F. Maltez and E. Carasek, "Chromium speciation and preconcentration using zirconium(IV) and zirconium(IV) phosphate chemically immobilized onto silica gel surface using a flow system and FAAS," Talanta, vol. 65, no. 2, pp. 537-542, 2005.

[14] S. Pramanik, S. Dey, and P. Chattopadhyay, "A new chelating resin containing azophenolcarboxylate functionality: synthesis, characterization and application to chromium speciation in wastewater," Analytica Chimica Acta, vol. 584, no. 2, pp. 469476, 2007.

[15] J. Nakajima, Y. Hirano, and K. Oguma, "Determination of lead in seawater by flow-injection on-line preconcentrationelectrothermal atomic absorption spectrometry after coprecipitation with iron(III) hydroxide," Analytical Sciences, vol. 19, no. 4, pp. 585-588, 2003.

[16] J. Guo, Y. Chai, R. Yuan, Z. Song, and Z. Zou, "Lead (II) carbon paste electrode based on derivatized multi-walled carbon nanotubes: application to lead content determination in environmental samples," Sensors and Actuators B, vol. 155, no. 2, pp. 639-645, 2011.

[17] H. A. Panahi, J. Morshedian, N. Mehmandost, E. Moniri, and I. Y. Galaev, "Grafting of poly[1-(N,N-bis-carboxymethyl)amino3-allylglycerol-co-dimethylacrylamide] copolymer onto siliceous support for preconcentration and determination of lead (II) in human plasma and environmental samples," Journal of Chromatography A, vol. 1217, no. 32, pp. 5165-5172, 2010.

[18] F. Pena-Pereira, I. Lavilla, and C. Bendicho, "Miniaturized preconcentration methods based on liquid-liquid extraction and their application in inorganic ultratrace analysis and speciation: a review," Spectrochimica Acta B, vol. 64, no. 1, pp. 1-15, 2009.

[19] H. Sereshti, V. Khojeh, and S. Samadi, "Optimization of dispersive liquid-liquid microextraction coupled with inductively coupled plasma-optical emission spectrometry with the aid of experimental design for simultaneous determination of heavy metals in natural waters," Talanta, vol. 83, no. 3, pp. 885-890, 2011.

[20] V. Andruch, C. C. Acebal, J. Škrlíková et al., "Automated on-line dispersive liquid-liquid microextraction based on a sequential injection system," Microchemical Journal, vol. 100, no. 1, pp. 7782, 2012.

[21] A. N. Anthemidis and M. Miró, "Recent developments in flow injection/sequential injection liquid-liquid extraction for atomic spectrometric determination of metals and metalloids," Applied Spectroscopy Reviews, vol. 44, no. 2, pp. 140-167, 2009.

[22] W. Chen, G. Zhong, Z. Zhou, P. Wu, and X. Hou, "Automation of liquid-liquid extraction-spectrophotometry using prolonged pseudo-liquid drops and handheld CCD for speciation of $\mathrm{Cr}(\mathrm{VI})$ and $\mathrm{Cr}(\mathrm{III})$ in water samples," Analytical Sciences, vol. 21, no. 10, pp. 1189-1193, 2005.

[23] J. L. Manzoori, M. Amjadi, and J. Abulhassani, "Ultra-trace determination of lead in water and food samples by using ionic liquid-based single drop microextraction-electrothermal atomic absorption spectrometry," Analytica Chimica Acta, vol. 644, no. 1-2, pp. 48-52, 2009.

[24] J. A. Baig, A. Hol, A. Akdogana et al., "A novel strategy for chromium speciation at ultra-trace level by microsample injection flame atomic absorption spectrophotometry," Journal of Analytical Atomic Spectrometry, vol. 27, pp. 1509-1517, 2012.

[25] P. G. Krishna, J. M. Gladis, U. Rambabu, T. P. Rao, and G. R. K. Naidu, "Preconcentrative separation of chromium(VI) species from chromium(III) by coprecipitation of its ethyl xanthate complex onto naphthalene," Talanta, vol. 63, no. 3, pp. 541-546, 2004.

[26] A. Karatepe, E. Korkmaz, M. Soylak, and L. Elci, “Development of a coprecipitation system for the speciation/preconcentration of chromium in tap waters," Journal of Hazardous Materials, vol. 173, no. 1-3, pp. 433-437, 2010.

[27] M. Alexovi, I. S. Balogh, J. Skrlikova, and V. Andruch, "A dispersive liquid-liquid micro-extraction procedure for UV-Vis spectrophotometric determination of chromium (VI) in water samples," Analytical Methods, vol. 4, pp. 1410-1414, 2012.

[28] M. S. Tehrani, P. A. Azar, S. W. Husain, and F. Shafaei, "Dispersive liquid-liquid microextraction of $\mathrm{Cr}(\mathrm{VI})$ in water and hair samples by electrothermal atomic absorption spectrometry," Asian Journal of Chemistry, vol. 22, no. 8, pp. 6302-6310, 2010.

[29] P. Hemmatkhah, A. Bidari, S. Jafarvand, M. R. M. Hosseini, and Y. Assadi, "Speciation of chromium in water samples using dispersive liquid-liquid microextraction and flame atomic absorption spectrometry," Microchimica Acta, vol. 166, no. 1-2, pp. 69-75, 2009.

[30] I. López-García, Y. Vicente-Martínez, and M. HernándezCórdoba, "Determination of very low amounts of chromium(III) and (VI) using dispersive liquid-liquid microextraction by in situ formation of an ionic liquid followed by electrothermal atomic absorption spectrometry," Journal of Analytical Atomic Spectrometry, vol. 27, pp. 874-880, 2012.

[31] M. Tuzen, D. Citak, and M. Soylak, "5-chloro-2-hydroxyaniline-copper(II) coprecipitation system for preconcentration and separation of lead(II) and chromium(III) at trace levels," Journal of Hazardous Materials, vol. 158, no. 1, pp. 137-141, 2008.

[32] U. Divrikli, A. A. Kartal, M. Soylak, and L. Elci, "Preconcentration of $\mathrm{Pb}(\mathrm{II}), \mathrm{Cr}(\mathrm{III}), \mathrm{Cu}(\mathrm{II}), \mathrm{Ni}(\mathrm{II})$ and $\mathrm{Cd}(\mathrm{II})$ ions in environmental samples by membrane filtration prior to their flame atomic absorption spectrometric determinations," Journal of Hazardous Materials, vol. 145, no. 3, pp. 459-464, 2007.

[33] H. F. Maltez, D. L. G. Borges, E. Carasek, B. Welz, and A. J. Curtius, "Single drop micro-extraction with O,O-diethyl dithiophosphate for the determination of lead by electrothermal atomic absorption spectrometry," Talanta, vol. 74, no. 4, pp. 800-805, 2008.

[34] E. M. Martinis, P. Bertón, J. C. Altamirano, U. Hakala, and R. G. Wuilloud, "Tetradecyl(trihexyl)phosphonium chloride ionic liquid single-drop microextraction for electrothermal atomic absorption spectrometric determination of lead in water samples," Talanta, vol. 80, no. 5, pp. 2034-2040, 2010.

[35] J. L. Manzoori, M. Amjadi, and J. Abulhassani, "Ultra-trace determination of lead in water and food samples by using ionic liquid-based single drop microextraction-electrothermal atomic absorption spectrometry," Analytica Chimica Acta, vol. 644, no. 1-2, pp. 48-52, 2009.

[36] M. T. Naseri, P. Hemmatkhah, M. R. M. Hosseini, and Y. Assadi, "Combination of dispersive liquid-liquid microextraction with flame atomic absorption spectrometry using microsample 
introduction for determination of lead in water samples," Analytica Chimica Acta, vol. 610, no. 1, pp. 135-141, 2008.

[37] M. T. Naseri, M. R. M. Hosseini, Y. Assadi, and A. Kiani, "Rapid determination of lead in water samples by dispersive liquidliquid microextraction coupled with electrothermal atomic absorption spectrometry," Talanta, vol. 75, no. 1, pp. 56-62, 2008.

[38] P. Liang and H. Sang, "Determination of trace lead in biological and water samples with dispersive liquid-liquid microextraction preconcentration," Analytical Biochemistry, vol. 380, no. 1, pp. 21-25, 2008.

[39] G. D. Matos, E. B. dos Reis, A. C. S. Costa, and S. L. C. Ferreira, "Speciation of chromium in river water samples contaminated with leather effluents by flame atomic absorption spectrometry after separation/preconcentration by cloud point extraction," Microchemical Journal, vol. 92, no. 2, pp. 135-139, 2009. 

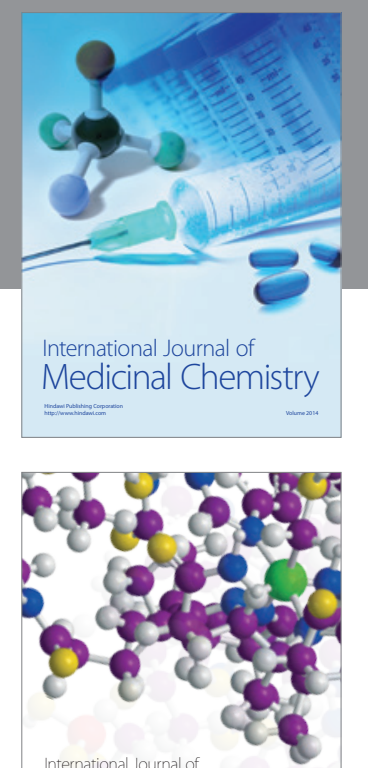

\section{Carbohydrate} Chemistry

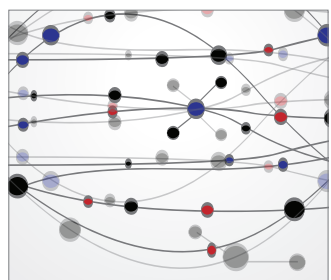

The Scientific World Journal
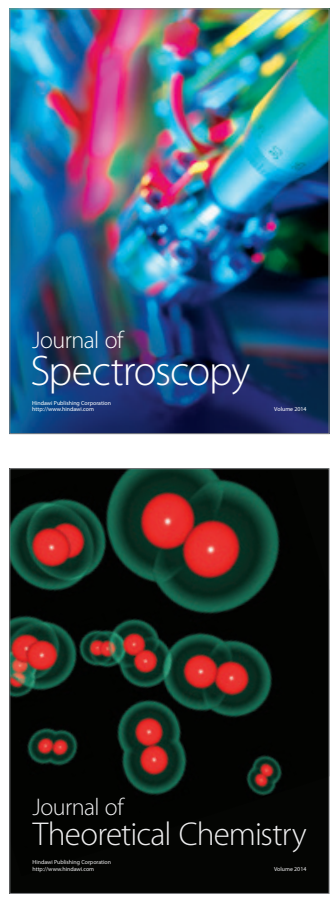
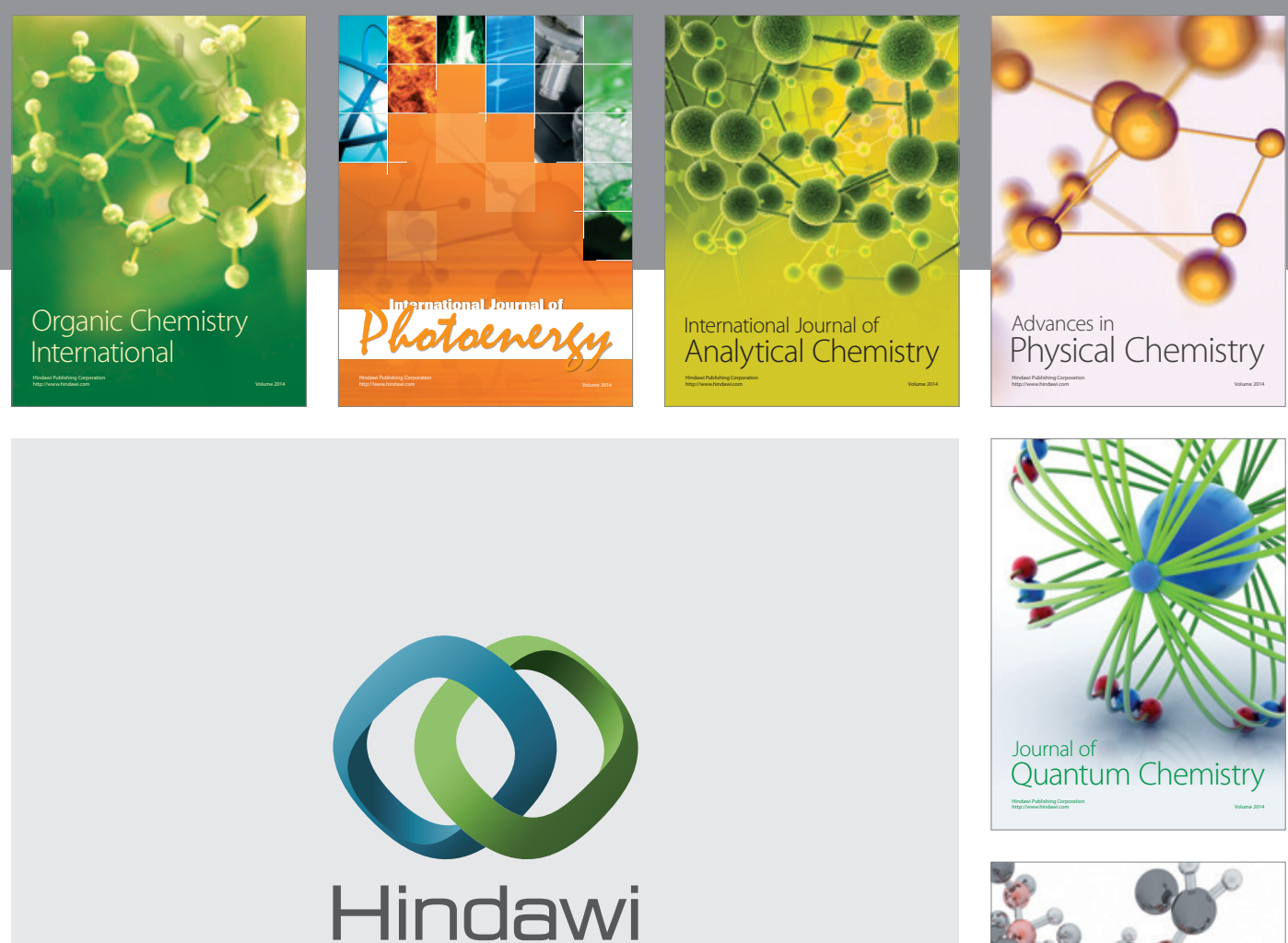

Submit your manuscripts at

http://www.hindawi.com

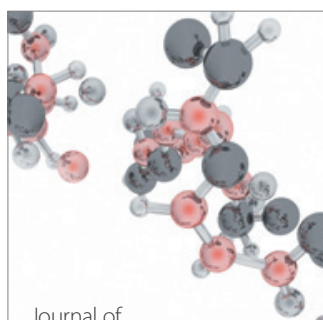

Analytical Methods

in Chemistry

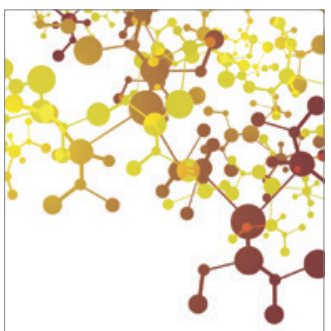

Journal of

Applied Chemistry

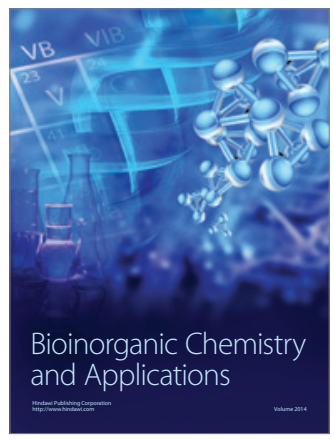

Inorganic Chemistry
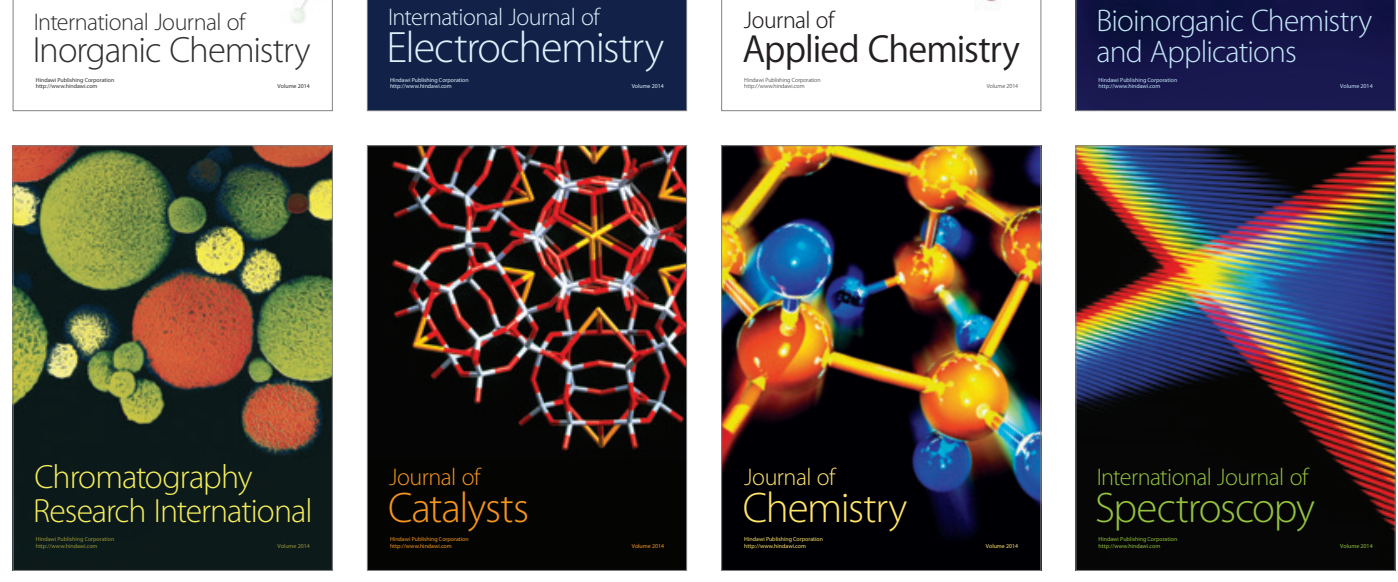